\title{
Naturally Occurring Hydrate Formation and Dissociation in Marine Sediment:
}

\section{Experimental Validation}

\author{
Avinash V. Palodkar and Amiya K. Jana*
}

Energy and Process Engineering Laboratory, Department of Chemical Engineering, Indian Institute of Technology Kharagpur, India 721302

\section{Supplementary Material}

*Corresponding author. Fax: +91 3222282250.

E-mail address: akjana@che.iitkgp.ac.in (A. K. Jana). 
Table S1. Model parameters for the $\mathrm{CH}_{4}$ and $\mathrm{CO}_{2}$ hydrate formation dynamics.

\begin{tabular}{|c|c|c|c|c|c|c|c|c|c|}
\hline \multirow{2}{*}{ Case } & \multicolumn{3}{|c|}{ Proposed model } & \multicolumn{4}{|c|}{ Palodkar et al. ${ }^{48}$} & \multicolumn{2}{|c|}{ Li et al. ${ }^{30}$} \\
\hline & $\alpha$ & $\begin{aligned} & K_{0}^{\mathrm{A}} \\
\times & 10^{-13}\end{aligned}$ & $\beta_{0}$ & $\alpha$ & $\begin{array}{c}K_{0}^{\mathrm{A}} \\
\times 10^{-10}\end{array}$ & $\begin{array}{l}\Delta E_{\mathrm{a}}^{\mathrm{B}} \\
\times 10^{-3}\end{array}$ & $\beta_{0}$ & $\begin{aligned} & K_{0}^{\mathrm{C}} \\
\times & 10^{-10}\end{aligned}$ & $\beta^{r c}$ \\
\hline $\begin{array}{l}\mathrm{CH}_{4} \| \text { Synthetic seawater }(3.55 \mathrm{wt} \%) \| \text { Silica } \\
\text { sand }(250-300 \mu \mathrm{m})^{\dagger}\|11.54 \mathrm{MPa}\| 272.27 \mathrm{~K}\end{array}$ & 0.1697 & 3768.10 & 0.9885 & 0.1670 & 115427.0 & 83.4011 & 0.5728 & - & - \\
\hline $\begin{array}{l}\mathrm{CH}_{4} \| \text { Synthetic seawater }(3.55 \mathrm{wt} \%) \| \text { Silica } \\
\text { sand }(150-250 \mu \mathrm{m})^{\dagger} \| 11.54 \mathrm{MPa} / 272.27 \mathrm{~K}\end{array}$ & 0.1784 & 3312.90 & 0.8579 & 0.1680 & 115427.0 & 83.5011 & 0.5818 & - & - \\
\hline $\begin{array}{c}\mathrm{CH}_{4} \| \text { Seawater }(3.03 \mathrm{wt} \%) \| \text { Silica sand } \\
(100-500 \mu \mathrm{m})^{\dagger}\|8 \mathrm{MPa}\| 277.2 \mathrm{~K}\end{array}$ & 0.1653 & 2.3856 & 0.9978 & 0.1165 & 0.2456 & 70.8951 & 0.2731 & 7.0894 & 19.3935 \\
\hline $\begin{array}{c}\mathrm{CO}_{2} \| \text { Seawater }(3.03 \mathrm{wt} \%) \| \text { Silica sand } \\
(100-500 \mu \mathrm{m})^{\dagger}\|3.5 \mathrm{MPa}\| 275.7 \mathrm{~K}\end{array}$ & 0.3853 & 0.1006 & 0.4573 & 0.3828 & 0.9929 & 75.1098 & 0.3765 & 2657.9938 & 4.6270 \\
\hline
\end{tabular}

${ }^{\mathrm{A}}$ mol of guest gas mol of $\mathrm{H}_{2} \mathrm{O}^{-1} \mathrm{~m}^{-2} \mathrm{~min}^{-1} ;{ }^{\mathrm{B}} \mathrm{J} \mathrm{mol}^{-1} ;{ }^{\mathrm{C}} \mathrm{kg} \mathrm{m}^{-2} \mathrm{~Pa}^{-1} \mathrm{~s}^{-1}$. ${ }^{\dagger}$ the particle size distribution. Here, $\beta^{r c}$ denotes the reduction coefficient. 
Table S2. Model parameters for the $\mathrm{CH}_{4}$ and $\mathrm{CO}_{2}$ hydrate dissociation dynamics.

\begin{tabular}{|c|c|c|c|c|}
\hline \multirow{2}{*}{ Case } & \multicolumn{3}{|c|}{ Proposed model } & \multirow{2}{*}{$\begin{array}{c}\text { Oyama et al. }{ }^{32} \\
\varphi\end{array}$} \\
\hline & $\alpha$ & $\begin{aligned} & K_{0}^{\mathrm{a}} \\
\times & 10^{-12}\end{aligned}$ & $\beta_{0}$ & \\
\hline $\begin{array}{c}\mathrm{CH}_{4} \| \text { Seawater }(3.03 \mathrm{wt} \%) \| 645.16 \mathrm{~g} \text { Silica sand } \\
(100-500 \mu \mathrm{m})^{\dagger}\|4.8 \mathrm{MPa}\| 287.15 \mathrm{~K}\end{array}$ & 0.2692 & 251.25 & 0.6979 & 1.0000 \\
\hline $\begin{array}{c}\mathrm{CH}_{4} \| \text { Pure water } \| 228.5 \mathrm{~g} \text { Silica sand }(150-630 \mu \mathrm{m})^{\dagger} \\
\|4.6 \mathrm{MPa}\| 281.15 \mathrm{~K}\end{array}$ & 0.3416 & 199.30 & 0.5536 & 0.7640 \\
\hline $\begin{array}{c}\mathrm{CH}_{4} \| \text { Pure water } \| 513.7 \mathrm{~g} \text { Silica sand }(150-630 \mu \mathrm{m})^{\dagger} \\
\|4.6 \mathrm{MPa}\| 281.15 \mathrm{~K}\end{array}$ & 0.4977 & 141.82 & 0.3940 & 0.7410 \\
\hline $\begin{array}{c}\mathrm{CH}_{4} \| \text { Pure water } \| \text { 914.1 g Silica sand }(150-630 \mu \mathrm{m})^{\dagger} \\
\|4.6 \mathrm{MPa}\| 281.15 \mathrm{~K}\end{array}$ & 0.5624 & 118.45 & 0.3290 & 0.7970 \\
\hline $\begin{array}{c}\mathrm{CH}_{4} \| \text { Pure water } \| 228.5 \mathrm{~g} \text { Silica sand }(150-630 \mu \mathrm{m})^{\dagger} \\
\|4.6 \mathrm{MPa}\| 287.15 \mathrm{~K}\end{array}$ & 0.5414 & 1255.10 & 0.3486 & 0.7910 \\
\hline $\begin{array}{c}\mathrm{CH}_{4} \| \text { Pure water } \| 513.7 \text { g Silica sand }(150-630 \mu \mathrm{m})^{\dagger} \\
\|4.6 \mathrm{MPa}\| 287.15 \mathrm{~K}\end{array}$ & 0.3556 & 202.30 & 0.5619 & 0.8390 \\
\hline $\begin{array}{c}\mathrm{CH}_{4} \| \text { Pure water } \| \text { 914.1 g Silica sand }(150-630 \mu \mathrm{m})^{\dagger} \\
\|4.6 \mathrm{MPa}\| 287.15 \mathrm{~K}\end{array}$ & 0.4255 & 175.68 & 0.4880 & 0.8430 \\
\hline $\begin{array}{c}\mathrm{CO}_{2} \| \text { Seawater }(3.0 \mathrm{wt} \%) \| 645.16 \mathrm{~g} \text { Silica sand } \\
(100-500 \mu \mathrm{m})^{\dagger}\|2.2 \mathrm{MPa}\| 279.7 \mathrm{~K}\end{array}$ & 0.4047 & 5.2554 & 0.5053 & 0.8790 \\
\hline $\begin{array}{c}\mathrm{CO}_{2} \| \text { Pure water } \| \text { 645.16 g Silica sand }(100-500 \mu \mathrm{m})^{\dagger} \\
\|2.2 \mathrm{MPa}\| 287.15 \mathrm{~K}\end{array}$ & 0.8423 & 6.4809 & 0.3565 & 1.0000 \\
\hline $\begin{array}{c}\mathrm{CO}_{2}-\mathrm{H}_{2}(40-60 \%) \| \text { Pure water } \| \text { 645.16 g Silica sand } \\
(150-630 \mu \mathrm{m})^{\dagger}\|7.5 \mathrm{MPa}\| 284.15 \mathrm{~K}\end{array}$ & 0.1791 & 2.0589 & 0.6863 & 0.3880 \\
\hline
\end{tabular}

${ }^{a}$ mol of guest gas mol of $\mathrm{H}_{2} \mathrm{O}^{-1} \mathrm{~m}^{-2} \mathrm{~min}^{-1}{ }^{\dagger}$ the particle size distribution. Here, $\varphi$ is the percentage contribution to the dissociation of the total heat input to the system. 


\section{Details of five experimental setups}

\section{Experimental arrangement $\mathbf{1}^{49}$}

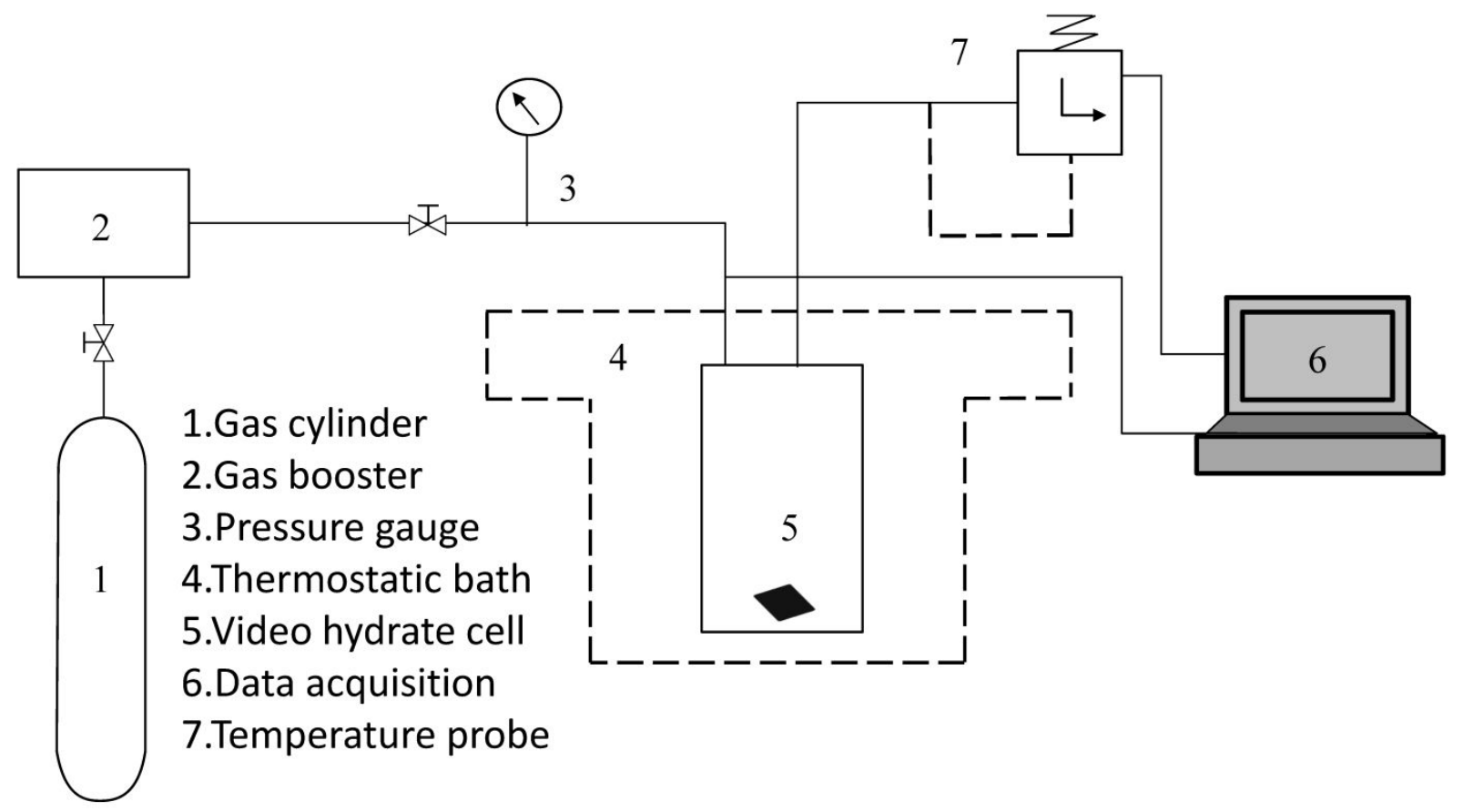

Fig. S1 Schematic of gas hydrate autoclave.

Figure S1 schematically shows a high-pressure hydrate autoclave experimental setup for methane hydrate formation in silica sand and seawater. The system consists of a constant volume hydrate cell with $250 \mathrm{~cm}^{3}$ capacity. The cell temperature is controlled by a thermostatic bath and measured by thermocouple with an accuracy of $0.1^{\circ} \mathrm{C}$. This apart, the cell pressure is monitored by a pressure transducer. Here, pure $\mathrm{CH}_{4}(99.99 \%)$ is used to form the hydrate in presence of silica sand [size range - (1) Fig. 2a: 250-300 $\mu \mathrm{m}$ and (2) Fig. 2b: 150-250 $\mu \mathrm{m}$ ] and synthetic seawater (3.55 wt $\%$ salinity) with (i) operating pressure $\left(P_{\mathrm{op}}\right)=11.54 \mathrm{MPa} \&$ operating temperature $\left(T_{\mathrm{op}}\right)=272.19 \mathrm{~K}$ for Fig. 2a and (ii) $P_{\text {op }}=11.54 \mathrm{MPa} \& T_{\mathrm{op}}=272.00 \mathrm{~K}$ for Fig. $2 \mathrm{~b}$. 


\section{Experimental arrangement $2^{50}$}

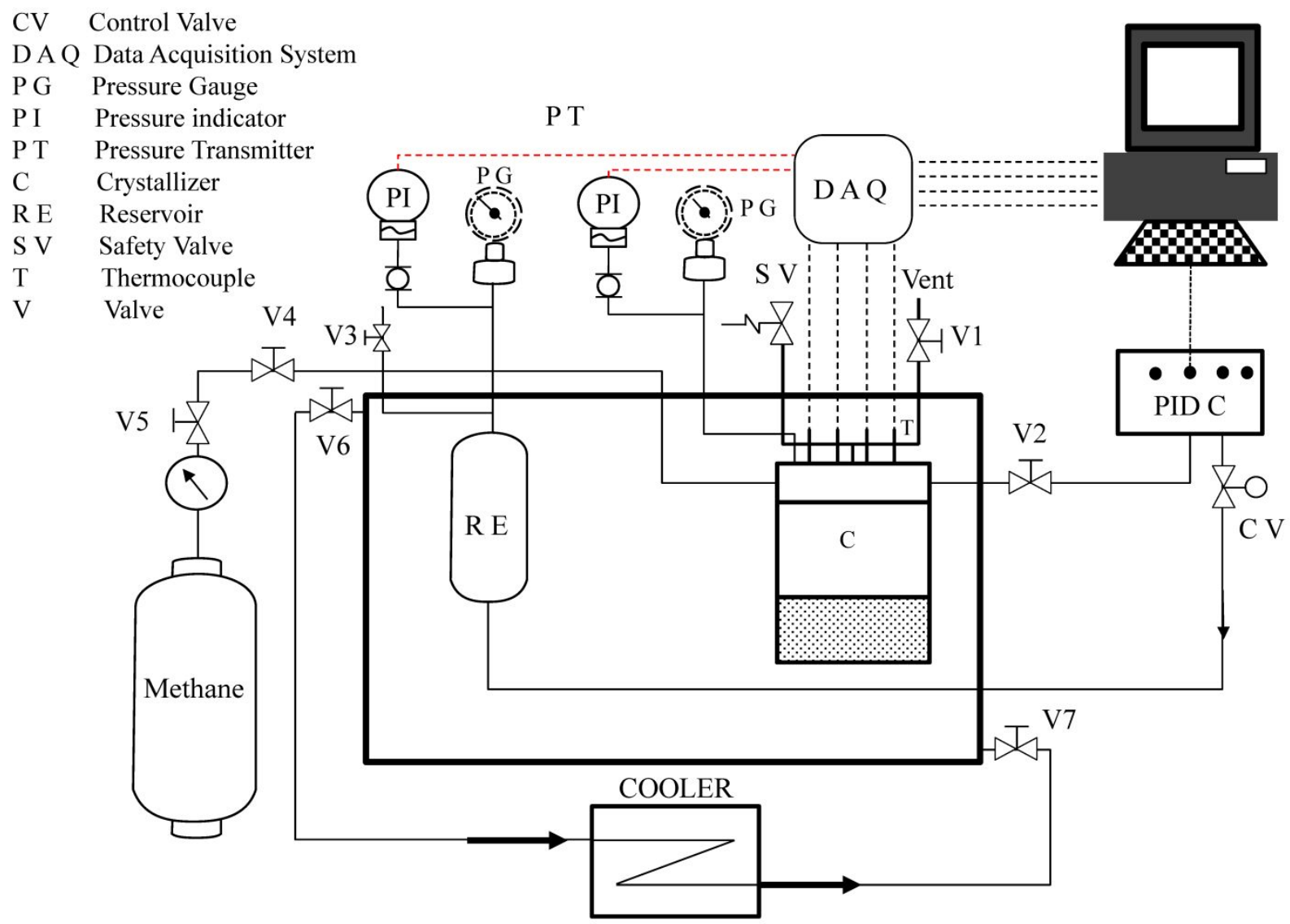

Fig. S2 Experimental setup for hydrate formation and dissociation studies in porous media.

The experimental system (Fig. S2) comprises of a high pressure crystallizer (SS-316) with internal volume of $1240 \mathrm{~cm}^{3}(\mathrm{ID}=10.2 \mathrm{~cm}$, Height $=15.2 \mathrm{~cm})$, which has four ports to accommodate thermocouples at various positions radially. A proportional integral derivative (PID) controller is employed to maintain a constant pressure during the decomposition experiment. The crystallizer pressure and temperature are picked up online in a personal computer (PC) using a data acquisition system and LabView software. Here, pure $\mathrm{CH}_{4}(99.9 \%)$ is used in the hydrate formation and decomposition in presence of Toyoura sand with particle size distribution of 100-500 $\mu \mathrm{m}$ and seawater of $3.03 \mathrm{wt} \%$ salinity. The operating conditions for different cases are given below:

\section{Hydrate Formation and Growth}

Fig. 3a $\left(\mathrm{CH}_{4}\right.$ hydrate): $3.03 \mathrm{wt} \%$ seawater, silica sand size range of $100-500 \mu \mathrm{m}, P_{\mathrm{op}}=8 \mathrm{MPa} \&$ $T_{\mathrm{op}}=277.20 \mathrm{~K}$.

\section{Hydrate Dissociation}


Fig. $4 \mathrm{a}\left(\mathrm{CH}_{4}\right.$ hydrate): $3.03 \mathrm{wt} \%$ seawater, silica sand size range of $100-500 \mu \mathrm{m}, P_{\mathrm{op}}=4.8 \mathrm{MPa} \&$ $T_{\mathrm{op}}=287.15 \mathrm{~K}$.

\section{Experimental arrangement $3^{51}$}

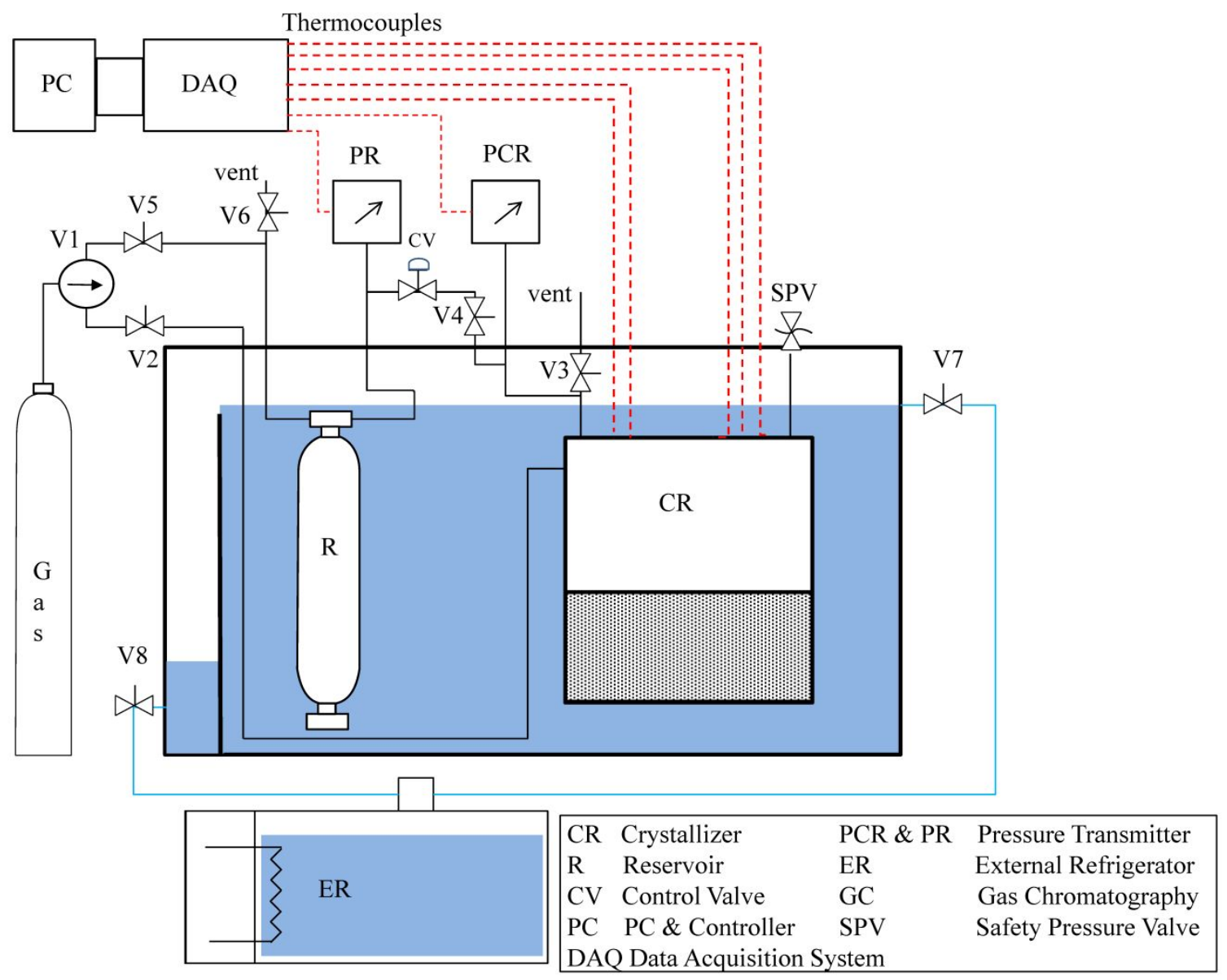

Fig. S3 Schematic of the experimental setup.

Fig. S3 depicts a cylindrical shaped stainless steel (316) crystallizer that has $10.2 \mathrm{~cm} \mathrm{ID,} 15 \mathrm{~cm}$ internal height and an internal volume of $1240 \mathrm{~cm}^{3}$. Five Omega copper-constantan T-type thermocouples are used to monitor the temperature at various points in the reactor. The crystallizer and $1000 \mathrm{~cm}^{3}$ gas reservoir are placed for water bath (temperature-controlled), coupling with an external refrigerator. This apart, a PID controller is equipped to maintain the constant pressure during hydrate decomposition. The silica sand bed has a bed height of $5 \mathrm{~cm}$, a weight (of silica sand) of $645.16 \mathrm{~g}$ and a void volume (of bed) of $140 \mathrm{ml}$. The case-wise experimental conditions are given below: 


\section{Hydrate Formation and Growth}

Fig. $3 \mathrm{~b}\left(\mathrm{CO}_{2}\right.$ hydrate): $3.03 \mathrm{wt} \%$ seawater, silica sand size range of $100-500 \mu \mathrm{m}, P_{\mathrm{op}}=3.5 \mathrm{MPa} \&$ $T_{\text {op }}=275.70 \mathrm{~K}$.

\section{Hydrate Dissociation}

Fig. $4 \mathrm{~b}\left(\mathrm{CO}_{2}\right.$ hydrate): $3.00 \mathrm{wt} \%$ seawater, silica sand size range of $100-500 \mu \mathrm{m}, P_{\mathrm{op}}=2.2 \mathrm{MPa} \&$ $T_{\text {op }}=279.70 \mathrm{~K}$.

Fig. 7a $\left(\mathrm{CO}_{2}\right.$ hydrate): pure water, silica sand size range of $100-500 \mu \mathrm{m}, P_{\mathrm{op}}=2.2 \mathrm{MPa} \& T_{\mathrm{op}}=$ $287.15 \mathrm{~K}$.

\section{Experimental arrangement $4^{52}$}

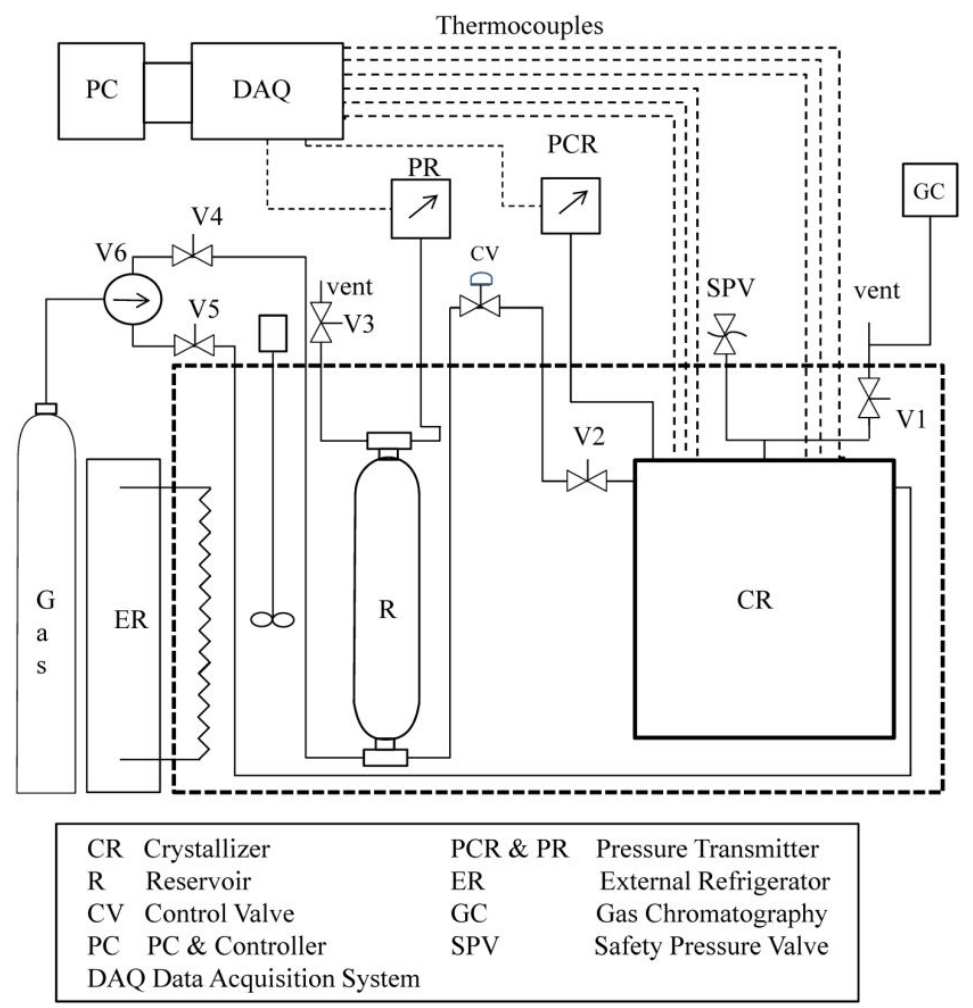

Fig. S4 Schematic of the experimental setup. 

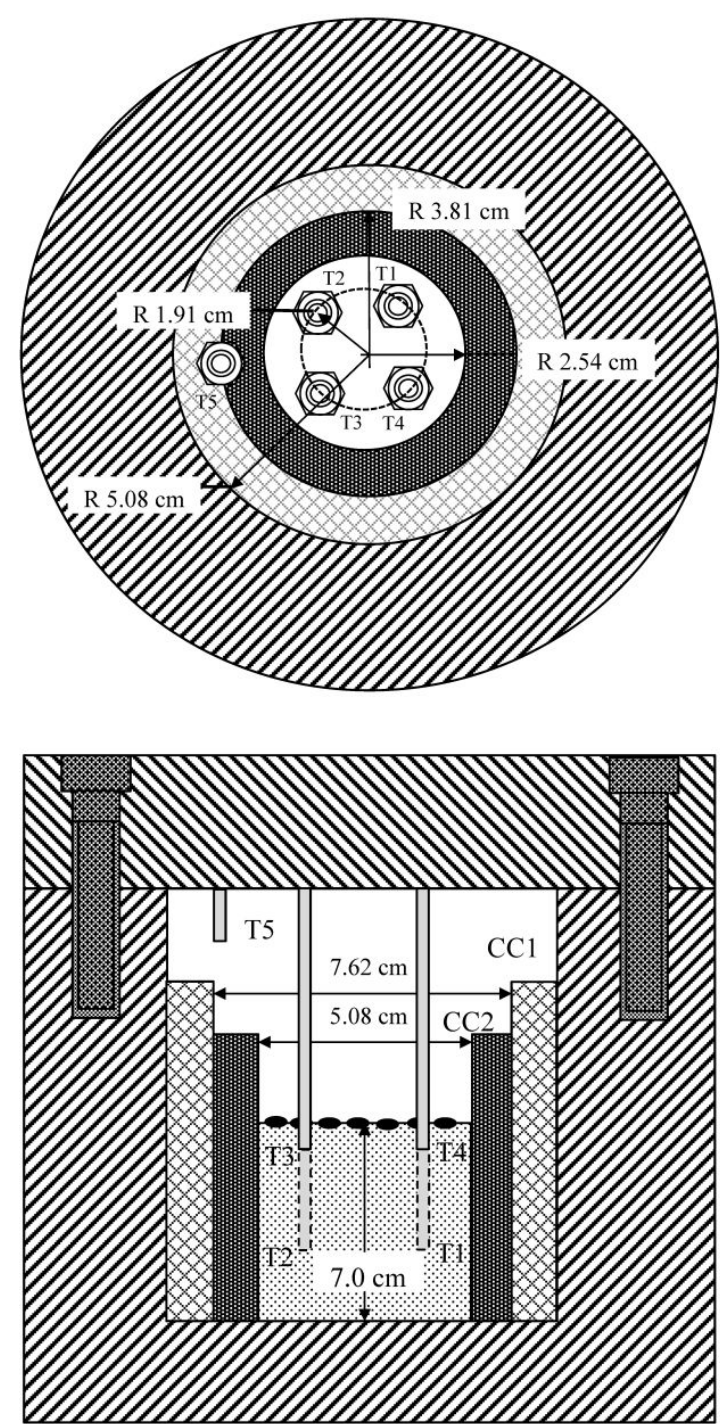

Fig. S5 Arrangement of the copper cylinders $\left(\mathrm{CC} 1-1^{\text {st }}\right.$ and $\left.\mathrm{CC} 2-2^{\text {nd }}\right)$ in the crystallizer and the location of the thermocouples.

Fig. S4 consists of a crystallizer (ID $=10.16 \mathrm{~cm}$, height $=15.24 \mathrm{~cm}$ ), gas reservoir, external refrigerator, data acquisition system and gas chromatography. The gas released during decomposition is collected in a reservoir. The crystallizer and the reservoir are immersed in a temperature-controlled water bath. Pressure is measured with Rosemount smart pressure transmitters (model 3051, Norpac controls, Vancouver, BC). The temperatures of the hydrate phase and the gas phase of the crystallizer are measured using Omega copper-constantan thermocouples with an uncertainty of $0.1 \mathrm{~K}$. In order to study the effect of the variable volume of 
the silica sand bed on hydrate formation and decomposition, two copper cylinders are placed inside the crystallizer as shown in Fig. S5. The first copper cylinder (CC1) has a diameter of $7.62 \mathrm{~cm}$ and the second one $(\mathrm{CC} 2)$ has $5.08 \mathrm{~cm}$. The wall thickness of both the cylinders is $1.27 \mathrm{~cm}$. The details of experimental conditions are as follows:

$\mathrm{CH}_{4}$ hydrate dissociation: pure water, $P_{\mathrm{op}}=4.6 \mathrm{MPa} \& T_{\mathrm{op}}=281.15 \mathrm{~K}$

1. Fig. $5 \mathrm{a}-228.5 \mathrm{~g}$ of silica sand (size range: $150-630 \mu \mathrm{m}$ ).

2. Fig. $5 \mathrm{~b}-513.7 \mathrm{~g}$ of silica sand (size range: $150-630 \mu \mathrm{m}$ ).

3. Fig. $5 \mathrm{c}-914.1 \mathrm{~g}$ of silica sand (size range: $150-630 \mu \mathrm{m}$ ).

- $\quad \mathrm{CH}_{4}$ hydrate dissociation: pure water, $P_{\mathrm{op}}=4.6 \mathrm{MPa} \& T_{\mathrm{op}}=287.15 \mathrm{~K}$

4. Fig. $6 \mathrm{a}-228.5 \mathrm{~g}$ of silica sand (size range: $150-630 \mu \mathrm{m}$ ).

5. Fig. $6 \mathrm{~b}-513.7 \mathrm{~g}$ of silica sand (size range: $150-630 \mu \mathrm{m}$ ).

6. Fig. $6 \mathrm{c}-914.1 \mathrm{~g}$ of silica sand (size range: $150-630 \mu \mathrm{m}$ ).

\section{Experimental arrangement $5^{53}$}

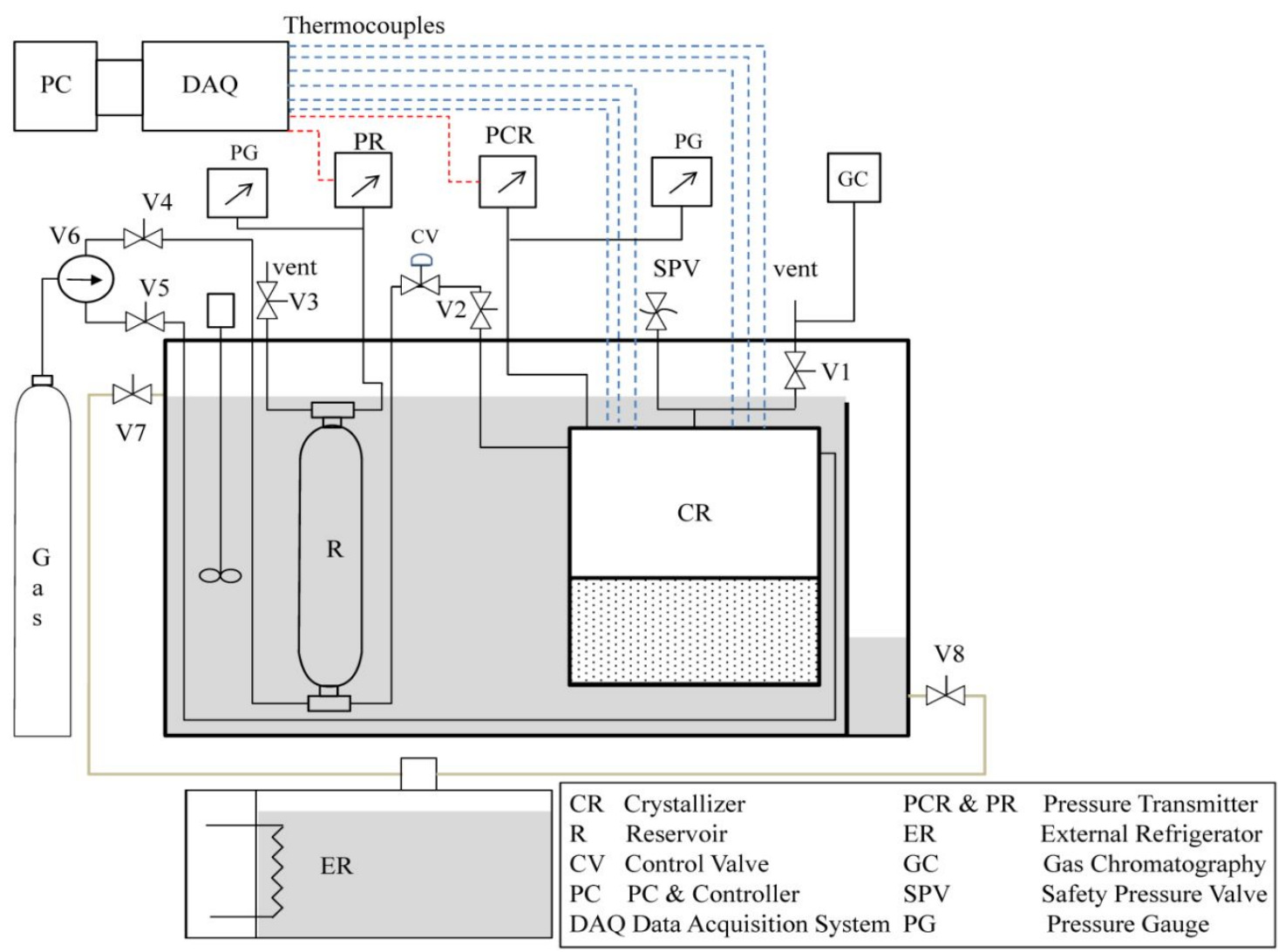

Fig. S6 Schematic of the experimental setup. 
Experimental setup depicted in Fig. S6 consists of a crystallizer [i.e., a cylindrical vessel with an ID of $10.2 \mathrm{~cm}$ and a height of $15.2 \mathrm{~cm}$ ] made up of 316 stainless steel. It has a volume of 1240 $\mathrm{cm}^{3}$. The crystallizer is immersed in a temperature-controlled water bath. Two Rosemount smart pressure transducers (model 3051S) are employed for pressure measurement with a maximum uncertainty of $0.1 \%$ of the span $(0-20,000 \mathrm{kPa})$. The temperatures of the hydrate phase and the gas phase of the crystallizer are measured using Omega copper-constantan thermocouples with an uncertainty of $0.1 \mathrm{~K}$. Here, $\mathrm{CO}_{2}-\mathrm{H}_{2}(40-60 \%)$ gas mixture is used that is typically generated in an integrated coal gasification cycle. The experimental conditions are given below:

- Fig. $7 \mathrm{~b}$ (Mixed $\mathrm{CO}_{2}$ hydrate): pure water, $645.16 \mathrm{~g}$ of silica sand with a size range of 100$500 \mu \mathrm{m}, P_{\text {op }}=7.5 \mathrm{MPa} \& T_{\text {op }}=284.15 \mathrm{~K}$. 